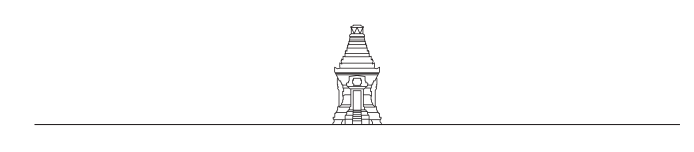

\title{
AKSI PENDIDIKAN LINGKUNGAN KAUM MUDA YOGYAKARTA DAN PEMANFAATAN MEDIA ONLINE
}

\author{
Adityo Nugroho \\ Padepokan ASA Wedomartani
}

Email: simbahadit@gmail.com

\begin{abstract}
Abstrak
Permasalahan lingkungan menjadi isu besar yang marak diperbincangkan pada beberapa dekade belakangan. Kerusakan lingkungan timbul akibat dari perubahan iklim, kepunahan sumber daya alam, sampai pada kerusakan lingkungan yang disebabkan oleh ulah manusia. Artikel ini berisi gambaran tentang keberadaan organisasi kaum muda berbasis lingkungan yang menginisiasi aksi pendidikan lingkungan dalam berbagai bentuk dan target grup serta memanfaatkan media online dalam aksi pendidikan lingkungan. Penelitian diadakan di Yogyakarta dengan sampel sejumlah 21 organisasi kaum muda berbasis lingkungan dan menggunakan metode penelitian kualitatif dan pengambilan data secara wawancara mendalam. Hasil penelitian menunjukan banyaknya dinamika yang dihadapi organisasi kaum muda berbasis lingkungan mulai dari pemilihan isu, kepengurusan, keanggotaan, pemilihan jenis aksi, pendanaan, sampai keberlangsungan organisasi. Terlepas dari hal tersebut, aksi pendidikan lingkungan yang telah dilakukan oleh kaum muda mampu memberikan alternatif dalam penyebaran informasi tentang lingkungan. Selain itu, keberadaan media online mampu menunjang berbagai aksi organisasi kaum muda berbasis lingkungan, termasuk aksi pendidikan lingkungan.
\end{abstract}

Kata Kunci : Kaum Muda, Organisasi, Pendidikan Lingkungan, Media Online.

\begin{abstract}
Environmental issues have become a worldwide concern in the last decade. Natural damage caused by climate change and the vanishment of natural resources as well as the damage caused by human being have become more severe through times. This article will discuss about the existence of youth oraganizations who put on actions engaged in environmental issues. Two of which are initiating actions of any form with various target environmental education and making the use of online media in these actions. The research has been conducted in Yogyakarta taking 21 environmental-based youth organizations. The applied method is qualitative data analyses af in-depth interview results. Findings show that there are a lot of dynamics have been experienced by these organizations, starting from selecting issues, organization management, membership, selecting actions, funding, to sustainbility of the organization itself. Despite of the challenges they face, the environmental education actions created by these youth organizations have become an alternative way to spread out informations regarding environmental issues to the society. In addition, they have demonstrated that online media can be beneficial to support actions such as the environmental education actions.
\end{abstract}

Key Word : Youth, Organization, Enviromental Education, Online Media 


\section{LATAR BELAKANG}

Pengertian pemuda jika dilihat dari usianya menurut UU No. 40 tahun 2009 adalah mereka yang berusia 16-30 tahun. Sementara dari Bank Dunia mendefinisikan pemuda di kisaran usia 15-24 tahun dan PBB melihatnya di rentang usia 16-25 tahun. Sedangkan menurut UNESCO (United Nations Educational, Scientific and Cultural Organization), pemuda didefinisikan sebagai periode transisi dari masa kanak-kanak yang tergantung dengan orang tua dan keluarga, menuju ke usia dewasa yang independen dan mempunyai kesadaran sebagai individu yang mempunyai ketergantungan sebagai anggota dari sebuah komunitas (Azca dkk, 2014). Beberapa definisi pemuda tersebut memperlihatkan bahwa mereka berada pada posisi transisi dari masa anak-anak menuju ke dewasa. Masa transisi ini kemudian membuat kaum muda memiliki karateristik dan ciri khas tersendiri, populer dengan sebutan budaya kaum muda (youth culture).

Budaya kaum muda ini telah berkembang dengan karakteristik identitas yang khas dan mampu membedakannya dengan kelompok anak-anak maupun orang tua. Tiga ciri budaya anak muda seperti diungkapkan Abercrombie (2010:643) adalah budaya anak muda lebih dekat dengan waktu luang daripada kerja, relasi sosial mereka terorganisir di seputar kelompok sekawan daripada keluarga atau teman perorangan, dan kelompok anak muda terutama tertarik pada 'gaya', dalam pengertian tertarik pada berbagai penanda eksternal, seperti penggunaan bahasa, selera dalam musik atau pakaian khas mereka, penerapan kegiatan senggang tertentu atau perhatian pada penampilan diri. Maka tak heran karakteristik tersebut membuat kaum muda cenderung untuk terlibat dalam suatu organisasi yang mayoritas berisi anak muda. Pernyataan pertama memperlihatkan bahwa kaum muda memang identik dengan waktu luang, sebuah organisasi mampu memberikan kesempatan bagi kaum muda untuk mengembangkan bakat, potensi, serta kreativitas. Kedua, organisasi yang berisi mayoritas anak muda memberi peluang mereka untuk membina relasi antar teman sebaya. Ketiga, setiap organisasi pemuda tentunya mengangkat suatu isu masing-masing yang kemudian menjadi daya tarik bagi kaum muda untuk terlibat di dalamnya.

Di sisi lain keberadaan kaum muda dilihat dari dua sudut pandang yang berbeda, satu sisi identik dengan berbagai permasalahan yang ditimbulkan akibat pemikiran dan perbuatannya sedangkan sisi lainnya dianggap mampu melakukan perubahan yang positif bagi lingkungan dan masyarakat luas. Berangkat dari penilaian sebagai pembuat permasalahan inilah yang kemudian membuat kaum muda berusaha untuk mengekspresikan diri melalui kegiatan-kegiatan yang positif, salah satunya dengan ikut dalam suatu organisasi. Dengan bergabung dalam organisasi maka kaum muda berusaha secara kolektif untuk menunjukan diri sebagai sekumpulan individu yang mampu melakukan kegiatan yang positif.

Banyak tipe-tipe organisasi yang didirikan dan diikuti oleh para generasi muda. Berbagai macam isu mereka angkat untuk dijadikan baha kajian. Salah satu jenis organisasi yang banyak diikuti kaum muda adalah organisasi kaum muda yang mengangkat isu-isu lingkungan atau oleh Suharko dkk (2014) lazim disebut Organisasi Pemuda Lingkungan (OPL). Ada beberapa karakteristik yang mencirikan keberadaan OPL ini sebagai berikut. Pertama, organisasi didirikan oleh aktivis pemuda dan oleh NGO nasional dan internasional untuk mewadahi keterlibatan pemuda dalam aksi-aksi lingkungan. Kedua, keanggotaannya umumnya adalah pemuda. Ketiga, organisasi ini didirikan sebagai upaya untuk merespon atas berbagai permasalahan lingkungan. Keempat, merupakan bagian dari dinamika organisasi 
masyarakat sipil yang memiliki derajat otonom relatif terhadap lembaga-lembaga negara.

Isu lingkungan dalam beberapa dekade ini sering diperbicangkan terkait krisis dan bencana lingkungan hidup yang sudah mendunia. Krisis dan bencana lingkungan hidup global ini diantaranya kerusakan lingkungan hidup, pencemaran lingkungan hidup, kepunahan sumber daya alam dan lingkungan hidup, kekacauan iklim global, dan masalah sosial terkait dampak lingkungan hidup (Keraf, 2010). Di sisi lain, isu-isu yang kekinian akan menjadi daya tarik bagi kaum muda untuk ikut terlibat, terutama melalui gerakan kolektif dalam bingkai organisasi.

Berbagai OPL ini memiliki banyak aksi yang ditujukan untuk konservasi lingkungan, baik yang berupa campaign atau turun langsung ke lapangan. OPL ini tersebar di berbagai kota besar di Indonesia dan pertumbuhannya pun semakin pesat berkat pemanfaatan media komunikasi dan media online yang semakin berkembang. Sebelum adanya berbagai organisasi pemuda yang peduli akan isu lingkungan, di Indonesia lebih dulu berkembang organisasi lingkungan seperti Wahana Lingkungan Hidup (WALHI) yang dibentuk tahun 1980 dan Sekretariat Kerja Sama Pelestarian Hutan (SKEPHI) yang berdiri tahun 1982.

Menurut Yappika dan CIVICUS, OPL masuk ke dalam ranah Civil Society Organization (CSO) karena merupakan 'organisasi pemuda' serta tergolong organisasi perlindungan atau pelestarian lingkungan. OPL juga termasuk ke dalam kategori CSO karena menekankan mobilisasi massa pada isu-isu tertentu, seperti lingkungan, gender, hak konsumen, hak asasi manusia, demokrasi, dan sebagainya (Suharko, 2005). Jika menilik pada kategorisasi Diamond, maka OPL termasuk CSO karena merupakan organisasi yang berorientasi terhadap isu (issue-oriented) dengan gerakan perlindungan lingkungan sebagai isu yang diangkat.
Aksi lingkungan yang sering dilakukan oleh OPL adalah pendidikan lingkungan. Pendidikan lingkungan bertujuan untuk memberi contoh serta mendidik masyarakat mengenai permasalahan lingkungan dan mendorong ke arah perubahan sikap serta perilaku terhadap lingkungan. Pendidikan lingkungan hidup menurut UNESCO pada Deklarasi Tbilisi tahun 1977 adalah suatu proses untuk membangun populasi manusia di dunia yang sadar dan peduli terhadap lingkungan total (keseluruhan) dan segala masalah yang berkaitan dengannya, dan masyarakat yang memiliki pengetahuan, ketrampilan, sikap dan tingkah laku, motivasi serta komitmen untuk bekerja sama, baik secara individu maupun secara kolektif, untuk dapat memecahkan berbagai masalah lingkungan saat ini, dan mencegah timbulnya masalah baru.

Menurut US EPA, pendidikan lingkungan adalah suatu proses yang memungkinkan para individu untuk menjelajahi isu-isu lingkungan, melibatkan diri dalam pemecahan masalah, dan mengambil tindakan untuk memperbaiki lingkungan. Sebagai hasilnya, para individu mengembangkan suatu pemahaman yang lebih mendalam tentang isu-isu lingkungan dan memiliki keahlian untuk membuat keputusan yang memadai dan dapat dipertanggungjawabkan (Suharko dkk, 2014). Pendidikan lingkungan sendiri mencakup lima komponen utama, yaitu kesadaran dan kepekaan terhadap lingkungan dan tantangan lingkungan, pengetahuan dan pemahaman terhadap lingkungan dan tantangan lingkungan, sikap peduli terhadap lingkungan dan motivasi untuk memperbaiki atau memelihara kualitas lingkungan, keahlian untuk mengidentifikasi dan membantu menghadapi tantangan lingkungan, serta partisipasi dalam aktivitas yang mengarah ke resolusi terhadap tantangan lingkungan. Berbagai upaya dilakukan kaum muda dalam usahanya untuk menjaga lingkungan, baik secara personal maupun lewat OPL. Aksi yang paling mudah dilakukan bagi 
kaum muda adalah dengan melakukan aksi pendidikan lingkungan. Kondisi mereka yang mayoritas masih mengenyam bangku sekolah dan kuliah, serta kemudahan dalam mengakses informasi turut mendukung pilihan aksi pendidikan lingkungan. Pendidikan lingkungan ini dilakukan OPL dalam berbagai bentuk aksi dan beragam target grup.

Kaum muda sendiri sebagai generasi milenial tentu sangat dekat dengan media online. Akses dunia maya dapat dengan mudah meraka jangkau lewat berbagai macam gawai yang mereka miliki. Budaya berselancar di dunia maya juga mereka bawa ke ranah organisasi. Berbagai OPL di Yogyakarta terindikasi menggunakan berbagai macam media online dalam berbagai kesempatan. Dunia virtual banyak digunakan dalam upaya menunjang berbagai gerakan lingkungan yang mereka lakukan, termasuk dalam berbagai aksi lingkungan. Patut menjadi kajian tersendiri sejauh mana peran media online dalam keberlangsungan organisasi pemuda yang berbasis pada isu lingkungan.

\section{METODE PENELITIAN}

Penelitian ini dilakukan di Yogyakarta pada akhir tahun 2015. Pemilihan kota ini karena banyaknya pelajar dan mahasiswa yang mengindikasikan banyaknya pemuda (16-30 tahun). Sebagai salah satu kota besar di Indonesia, Yogyakarta juga dikenal memiliki banyak komunitas yang bergelut di berbagai macam isu kajian, salah satunya isu lingkungan. Penelitian menggunakan metode penelitian kualitatif dengan pengumpulan data secara wawancara. Wawancara digunakan untuk mendapatkan data primer dari informan yang berkecimpung langsung di dunia OPL. Informan merupakan ketua masing-masing OPL atau pengurus yang berkompeten. Teknik pengambilan sampel pada penelitian ini menggunakan sampling purposive, di mana penentuan sampel dengan pertimbangan tertentu sesuai tujuan penelitian.

Di Yogyakarta ditemukan sejumlah 21 OPL sesuai karakteristik yang ditentukan, yaitu IAAS LC UGM, Trashbag Community Yogyakarta, Earth Hour (EH) Jogja, Water Forum Kalijogo, Waterplant Community, Together We Save Energy (TWSE) Community, Pemuda Tata Ruang (Petarung), Gama Earth UGM, Jogja Berkebun, Komunitas Mahasiswa Sentra Energi (KAMASE), Taman Kota Jogja, Shalink WALHI Yogyakarta, Kemangteer Jogja, Hilo Green Community Jogja, Forum Pelajar Peduli Lingkungan (FPPL) Jogja, Sedekah Hijau, Youth For Climate Change DIY, Green Tech UPN, Sobat Bumi Jogja, Green Peace Youth Jogja, dan Koalisi Pemuda Hijau (Kophi) Jogja.

Tabel 1. Usia dan Jabatan Informan.

\begin{tabular}{||l|c|c|c|c||}
\hline \multirow{2}{*}{ Posisi di OPL } & \multicolumn{3}{|c|}{ Usia } & \multirow{2}{*}{ Total } \\
\cline { 2 - 5 } & $16-20$ & $21-25$ & $26-30$ & \\
\hline Ketua & 5 & 10 & 1 & 16 \\
\hline Pengurus & 2 & 2 & 1 & 5 \\
\hline \multicolumn{1}{|c|}{ Total } & 7 & 12 & 2 & 21 \\
\hline
\end{tabular}

Sumber: Pengolahan Data Lapangan.

Jumlah total responden sebanyak 21 orang yang mewakili OPL masing-masing. Sebanyak 16 responden adalah ketua OPL, sedangkan sisanya 5 responden adalah pengurus yang ditunjuk langsung oleh ketua OPL untuk mewakili. Data tersebut memperlihatkan bahwa posisi responden penelitian mampu mewakili OPL yang menjadi sampel penelitian. Usia responden berada di kisaran 16-30 sesuai dengan rentang usia pemuda menurut UU No. 40 tahun 2009. Populasi responden terbesar ada di rentang usia 21-25 tahun berjumlah 12 orang, diikuti responden dengan rentang usia 16-20 tahun sejumlah 7 orang, dan sisanya 2 orang berusia 26-30 tahun. 


\section{ORGANISASI PEMUDA LINGKUNGAN (OPL) DI YOGYAKARTA}

Pada pertengahan tahun 2015, beberapa anak muda yang tergabung dalam Forum Jogja Peduli berupaya mengumpulkan komunitas-komunitas muda di Yogyakarta dalam acara bertajuk Silaturahmi Komunitas. Konsepnya adalah menjaring komunitas-komunitas kaum muda yang tersebar di Yogyakarta. Terkumpul ratusan komunitas dengan berbagai fokus isu kajian. Beberapa bisa diklasifikasikan ke dalam beberapa kategori, yaitu komunitas yang berfokus pada isu pendidikan, kesehatan, lingkungan hidup, literasi, dan lain-lain. Salah satu kategori komunitas kaum muda yang menjamur di Yogyakarta adalah komunitas peduli lingkungan hidup atau OPL.

Gambar 1. Logo Berbagai Organisasi Pemuda Lingkungan di Yogyakarta.

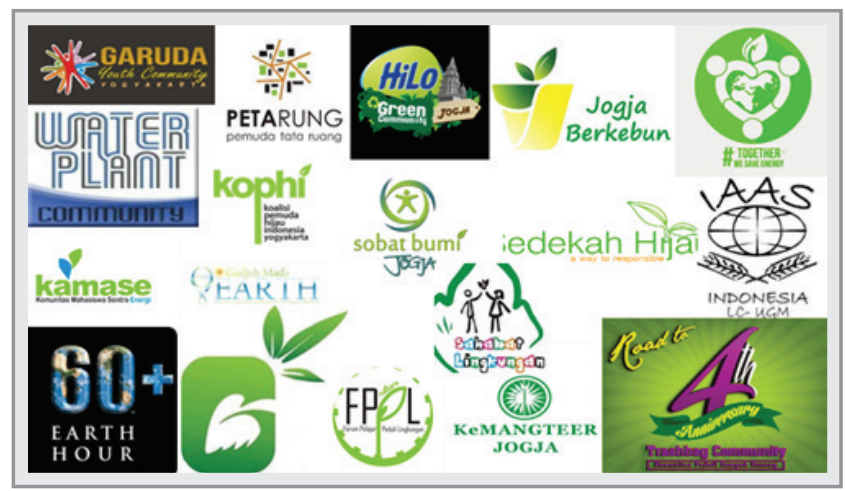

Sumber: Media Online Masing-masing OPL.

Gambar di atas merupakan logo dari berbagai macam OPL di Yogyakarta. Kecenderungan logo menggunakan warna hijau yang identik dengan lingkungan hidup. Yang menarik adalah penggunaan bahasa asing dalam menamai OPL masing-masing. Tercatat ada 11 OPL menggunakan kata-kata asing untuk memberi nama OPL yang didirikan, lebih dari 50\% dari total keseluruhan OPL yang diteliti.
Grafik 1. Tahun Berdiri OPL di Yogyakarta $(\mathrm{n}=21)$.

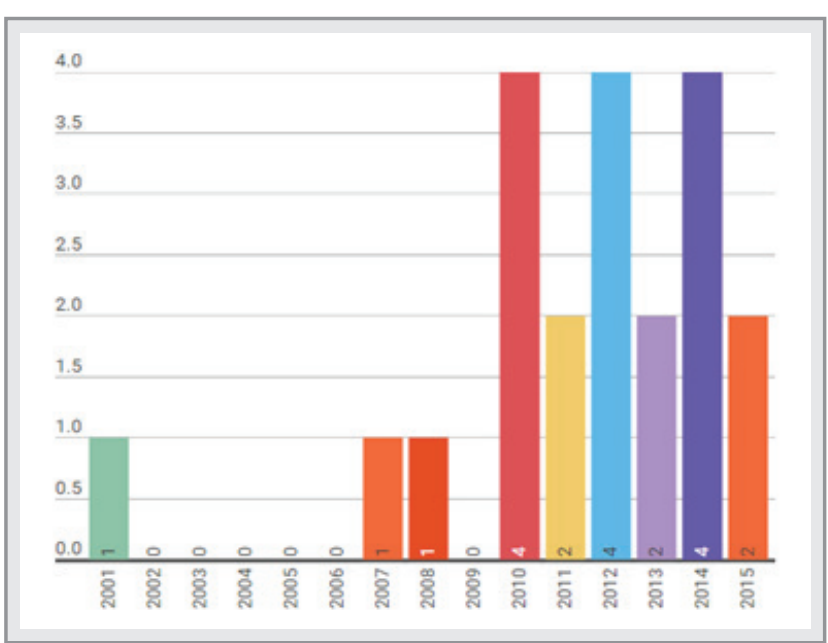

Sumber: Pengolahan Data Lapangan.

Grafik di atas memperlihatkan bahwa perkembangan OPL di Yogyakarta meningkat dalam kurun waktu 2010-2015, sebanyak 18 OPL berdiri. Sedangkan dalam kurun waktu 2007-2008 berdiri 2 OPL. Satu OPL paling senior didirikan tahun 2001 yang telah berusia 14 tahun. Ini menandakan bahwa isu lingkungan menjadi isu pilihan yang dipakai kaum muda untuk mendirikan sebuah organisasi. Atau malah sebaliknya, kesadaran akan lingkungan yang tinggilah yang membuat kaum muda tergerak untuk peduli dengan mendirikan OPL.

Pengorganisasian adalah landasan utama dari keberlangsungan suatu OPL. Suatu OPL membutuhkan dasar utama sebagai landasan dalam berorganisasi. Landasan dasar itu dapat berupa visi misi atau tujuan atas pendirian organisasi. Visi misi atau tujuan dari OPL dapat dilacak dari sejarah berdirinya organisasi. Pendirian suatu OPL tentu tak lepas dari berbagai kisah yang melatarbelakanginya. Mulai dari pengalaman pribadi para pendirinya atas fenomena lingkungan, simpati atas berbagai permasalah lingkungan, hasil jejaring dari OPL kota lain, ataupun berawal dari gerakan yang berakhir dengan pendirian OPL. 
Pentingnya visi misi ataupun tujuan ini adalah agar OPL memiliki pegangan dalam melakukan kegiatan-kegiatannya. Dengan adanya visi misi ataupun tujuan ini bisa menjadi alat kontrol bagi pengurus serta anggota-anggotanya untuk mengambil kebijakan. Kontrol agar setiap generasi kepengurusan mampu menghasilkan aksi-aksi yang sesuai dengan visi misi, serta kontrol agar aksi-aksi yang dilakukan tidak pula keluar dari jalur visi misi. OPL akan bisa berjalan dengan harmonis ketika ada guide yang sudah dimiliki dari generasi kepengurusan sebelumnya. Dengan adanya acuan ini akan mempermudah OPL untuk mengambil kebijakan organisasi, seperti pada kebijakan kepengurusan, perekrutan anggota, ataupun aksi-aksi lingkungan. Di sisi lain banyak permasalahan yang ada di OPL ditimbulkan dari melencengnya arah kebijakan organisasi dari visi misi awal. Maka di sinilah pentingnya suatu OPL memiliki visi misi atau tujuan organisasi.

Grafik 1. Tipe OPL di Yogyakarta $(\mathrm{n}=21)$.

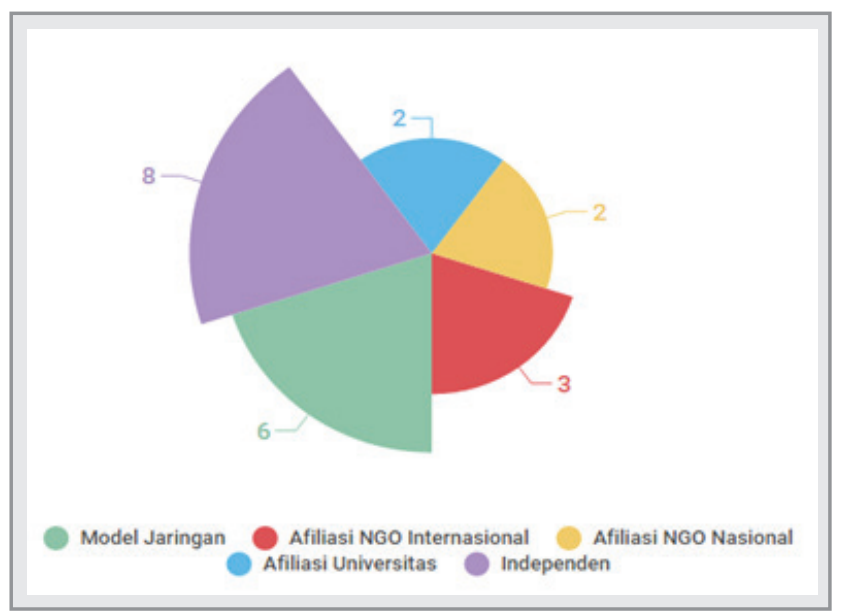

Sumber: Pengolahan Data Lapangan.

Tipe OPL juga sangat berpengaruh dalam keberlangsungan pengelolaan organisasi. Perbedaan tipe OPL akan memberikan dampak yang berbeda. Dilihat dari tipenya berbagai OPL yang aktif di Yogyakarta terkategori dalam berbagai variasi. OPL di Yogyakarta banyak yang memilih untuk independen, tidak terikat dan terafiliasi dengan pihak manapun. Paling banyak, yaitu 8 OPL masuk dalam tipe independen. OPL yang masuk tipe ini adalah Waterplant Community, Together We Save Energy (TWSE) Community, Pemuda Tata Ruang (Petarung), Gama Earth UGM, Taman Kota Jogja, Forum Pelajar Peduli Lingkungan (FPPL) Jogja, Sedekah Hijau, dan Green Tech UPN. Tipe ini cenderung banyak dipilih oleh OPL karena mereka tidak memiliki ikatan dengan pihak mana pun. OPL tipe ini memposisikan diri untuk mandiri sehingga bebas untuk menentuka arah kebijakan, tidak harus mengikuti pihak afiliasi ataupun jaringan. Walaupun OPL tipe independen ini sebenarnya memiliki kelemahan dalam hal pengorganisasian. Ketiadaan pihak afiliasi ataupun jaringan pusat membuat OPL tipe independen harus mampu mengelola keberlangsungan komunitas. Tidak seperti tipe afiliasi ataupun jaringan yang mendapat arahan dan dukungan dari pihak afiliasi ataupun jaringan pusat. Dari segi pendanaan, ketiadaan afiliasi otomatis harus dibayar mahal dengan ketiadaan sumber dana tetap.

Selanjutnya tipe jaringan di Yogyakarta terdapat 6 OPL, di antaranya Trashbag Community Yogyakarta, Jogja Berkebun, Hilo Green Community Jogja, Youth For Climate Change DIY, Sobat Bumi Jogja, dan Koalisi Pemuda Hijau (Kophi) Jogja. Tipe ini banyak muncul di berbagai kota di Indonesia termasuk Yogyakarta, sistem OPL tipe ini awalnya didirikan di pusat (mayoritas Jakarta) untuk kemudian berkembang dan didirika di kota-kota lain sebagai chapter dari pusat. Tipe ini cenderung memiliki koordinasi terpusat yang wajib dipatuhi oleh chapter di daerah, walaupun OPL tipe jaringan di tiap daerah juga memiliki otonomi tersendiri untuk menentukan arah kebijakan. Tentunya mereka memiliki kelebihan dalam segi pendanaan yang teratur namun harus terikat dengan pihak jaringan ataupun afiliasi.

Sedangkan sisanya terbagi 3 OPL bertipe 
afiliasi NGO Internasional, yaitu IAAS LC UGM, Earth Hour (EH) Jogja, dan Green Peace Youth Jogja. Ada 2 OPL bertipe afiliasi NGO Nasional, Shalink WALHI Yogyakarta dan Kemangteer Jogja. Serta 2 OPL lain terafiliasi dengan institusi universitas, Water Forum Kalijogo dan Komunitas Mahasiswa Sentra Energi (KAMASE). OPL terafiliasi NGO Internasional ataupun Nasional menjadi bagian dari perluasan basis organisasi untuk menjangkau kalangan muda. Sedangkan OPL tipe afiliasi universitas biasanya merupakan OPL yang didirikan dan berbasis di universitas tertentu. OPL tipe terafiliasi ini memiliki beberapa keuntungan, diantaranya berkaitan dengan program kerja dan pendanaan. Ada kasus unik pada beberapa OPL di Yogyakarta, awalnya memilih menjadi suatu tipe OPL tertentu namun seiring berjalannya waktu bermetamorfosis menjadi tipe yang lain guna menyesuaikan kebutuhan organisasi.

Selanjutnya adalah bentuk kepengurusan dari OPL yang bersangkutan. Bentuk kepengurusan ini dapat berupa posisi pemegang kebijakan tertinggi, susunan bagan kepengurusan, serta tugas dari masing-masing posisi dalam OPL. Posisi pemegang kebijakan tertinggi biasanya diisi oleh satu orang dengan sebutan ketua, koordinator, atau bahkan presiden. Posisi kepengurusan lain di dalam OPL juga akan turut berpengaruh dalam pengorganisasian. Personal dalam posisi-posisi ini mempunyai peran untuk turut membantu menggerakan roda organisasi membantu ketua. Biasanya akan terdapat pengurus inti yang membantu tugas ketua, seperti bendahara dan sekretaris. Di bawahnya akan terdapat kelompok-kelompok personal yang menjalankan tugas khusus, biasanya dinamakan divisi, departemen, atau sebutan lain yang sejenis. Nama masing-masing divisi akan sangat berpengaruh tergantung kebijakan dari OPL yang bersangkutan, seperti internal, eksternal. media, pengembangan, aksi, hubungan masyarakat, usaha dana, dan lainnya.

Peran penting kepengurusan ada pada tugas yang diemban oleh masing-masing posisi pengurus. Pada dasarnya kepengurusan ada untuk mengatur jalannya roda organisasi. Sedikit banyaknya posisi dalam kepengurusan disesuaikan dengan kebutuhan organisasi. Ada yang memilih untuk memakai kepengurusan yang ramping, ada pula yang memilih untuk menggemukan kepengurusan. Rekrutmen kepengurusan masing-masing OPL juga beragam, khusus untuk ketua pemilihan dilakukan berdasarkan musyawarah mufakat ataupun dengan sistem voting.

Sumber dana merupakan faktor penting dalam pengelolaan OPL. Kebutuhan untuk terus menggerakan roda kepengurusan serta aksi-aksi lingkungan tentu membutuhkan dana yang tidak sedikit. Permasalahannya OPL adalah organisasi non-profit, bukan lembaga yang berorientasi untuk mencari keuntungan semata. Perlu ada pengelolaan sumber dana bagi para OPL, terutama sumber pemasukan. Ada beberapa macam cara pencarian dana yang bisa didapat oleh OPL, diantaranya dari pihak jaringan/afiliasi, iuran anggota, pembuatan divisi khusus usaha dana, menerima kerjaan dari pihak lain, ataupun membangun entrepreneurship berbasis lingkungan.

OPL terafiliasi pada suatu lembaga atau jejaring antar kota punya pemasukan tetap, tapi buat yang bertipe independen tentu mereka harus memutar otak lebih keras untuk mendapatkan pemasukan. Iuran anggota merupakan salah satu cara paling simpel untuk mendapatkan pemasukan. Iuran merupakan konsep pembagian beban organisasi secara bersama-sama dalam bentuk nominal uang. Iuran anggota dapat berupa iuran rutin (mingguan, dua mingguan, bulanan, dua bulanan) ataupun iuran yang baru dilakukan ketika OPL akan melakukan aksi lingkungan. Kelemahannya hanya pada konsistensi anggota untuk dapat memenuhi iuran. Selain dilihat dari segi nominalnya juga karena anggota akan merasa tereksploitasi dari segi keharusan untuk mengeluarkan sejumlah 
7 OPL memiliki anggota aktif berkisar 21-40 orang, sedangkan hanya 1 OPL yang beranggotakan antara 41-50 orang. Jumlah anggota aktif tentunya sedikit banyak akan berbeda dengan jumlah anggota yang terdaftar. Jumlah anggota aktif lebih merepresentasikan kuantitas orang yang benarbenar ikut terlibat dalam kegiatan OPL yang bersangkutan.

Grafik 4. Sistem Rekrutmen Anggota OPL di Yogyakarta $(n=21)$.

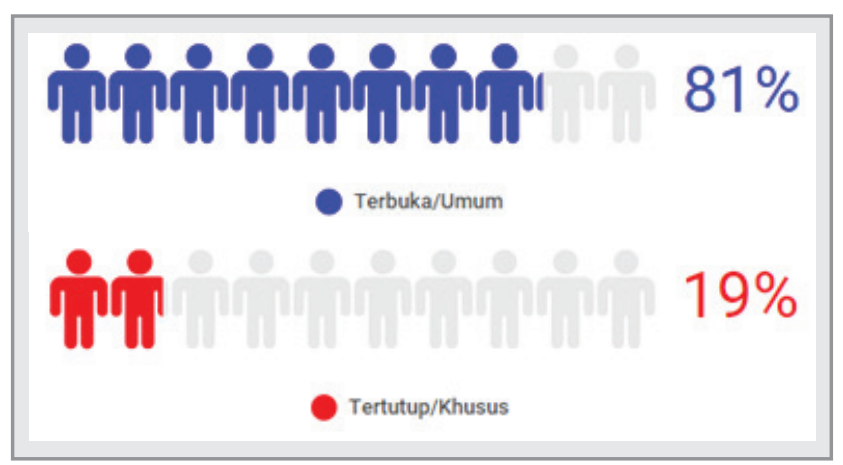

Sumber: Pengolahan Data Lapangan.

Rekrutmen anggota dari masing-masing OPL juga berbeda, $81 \%$ memperbolehkan siapa saja untuk ikut bergabung dan 19\% membatasi latar belakang calon anggotanya. Mayoritas OPL di Yogyakarta tidak mempersulit calon anggotanya, asalkan masuk dalam kualifikasi umur kaum muda sudah cukup untuk menjadi calon anggota. Sedangkan bagi OPL yang menggunakan sistem tertutup/khusus biasanya mengharuskan calon anggota merupakan bagian dari institusi tertentu, semisal terafiliasi pada universitas.. Tipe OPL afiliasi universitas biasanya hanya membatasi anggotanya pada personal yang memiliki disiplin ilmu jurusan/fakultas terkait. Karena mayoritas anggota OPL di Yogyakarta adalah mahasiswamahasiswa di perguruan tinggi.

Setidaknya OPL dalam melakukan rekrutmen dapat memilah calon anggotanya dengan tepat, walaupun pada akhirnya seleksi alam yang akan membuktikan. Paling tidak OPL harus memiliki alur yang jelas untuk rekrutmen anggota demi meminimalisir keanggotaan pasif. Berbagai macam cara dalam rekrutmen bisa dilakukan, yang paling mendasar biasanya diawali dari menyebarkan publikasi tentang adanya rekrutmen anggota. Bagi calon anggota yang sudah mendaftar berkewajiban untuk mengirimkan data diri beserta essay tentang dunia lingkungan hidup. Anggota kemudian akan diundang untuk melakukan wawancara, melihat sejauh mana keinginan menjadi anggota OPL dan pengetahuan akan dunia lingkungan hidup. Setelah itu baik calon anggota yang terpilih atau kesemua anggota yang mendaftar wajib mengikuti pelatihan dasar. Baru pada akhirnya nanti ditentukan apakah calon anggota tersebut layak menjadi anggota, atau pada beberapa OPL harus melalui beberapa aksi dulu baru diakui menjadi anggota.

Cara untuk bisa menjaga keaktifan anggota adalah dengan melakukan upgrading atau kegiatan yang bertujuan untuk meningkatkan kemampuan anggotanya. Bentuknya bisa berupa diskusi rutin ataupun tugas personal/kelompok yang dikerjakan dalam jangka waktu yang lama. Paling tidak untuk membuat anggota menjadi aktif adalah dengan menumbuhkan loyalitas pada diri mereka. Ada OPL yang menumbuhkan rasa loyalitas anggota dengan mengajak anggotanya untuk berkegiatan bersama di luar kepentingan OPL. Misalkan saja sekedar makan bareng, nonton bareng, wisata bareng, dan kegiatan lain di luar kepentingan organisasi. Dari sini akan tumbuh rasa solidaritas pertemanan diantara anggota yang akan terbawa ketika mereka mengelola OPL.

Tentu tidak semua OPL melakukan hal yang sama. Ada pula OPL yang dengan senang hati menerima calon anggota baru asalkan mau bergabung. Ini dilakukan oleh beberapa OPL yang baru berdiri di tengah susahnya mereka mencari anggota. 


\section{PENDIDIKAN LINGKUNGAN OPL DI YOGYAKARTA}

Menurut Nomura dan Hendarti (2005) bahwa pendidikan lingkungan hidup dapat disampaikan melalui tiga tipe cara. Pertama, pendidikan formal yang diselenggarakan oleh sekolah-sekolah, perguruan tinggi, dan lembaga-lembaga pemerintah yang memiliki kewenangan untuk itu. Kedua, pendidikan non-formal yaitu pendidikan yang diorganisasikan tidak melalui sekolah formal atau pelembagaan. Pengetahuan, keahlian, dan nilai-nilai diajarkan oleh keluarga, teman, atau anggotaanggota suatu komunitas. Secara umum pendidikan non-formal ini biasanya dilakukan oleh organisasiorganisasi nonpemerintah (NGO) yang peduli pada lingkungan. Ketiga, pendidikan informal yaitu pendidikan sehari-hari dan terus menerus dari pengalaman hidup di luar pendidikan formal dan non-formal yang terorganisasikan. Ini mencakup pembelajaran dalam keluarga, tempat kerja, dan kehidupan sosial. OPL di Yogyakarta turut berkontribusi melalui pendidikan lingkungan non-formal, pengetahuan serta nilai-nilai lingkungan diajarkan oleh komunitas kaum muda. Pendidikan lingkungan non-formal ini dilakukan melalui berbagai aksi baik langsung maupun tidak langsung.

Pendidikan lingkungan hidup menurut Jensen \& Schnack (1997) bisa dilakukan dalam bentuk aksi lingkungan langsung (direct environmental action) dan aksi lingkungan tidak langsung (indirect environmental action). Aksi pendidikan langsung dilakukan dengan memberikan kontribusi langsung untuk menjaga lingkungan atau mengatasi permasalahan lingkungan, seperti pemanfaatan taman kota, pembersihan sungai, dan lain-lain. Sedangkan aksi tidak langsung berupa tindakan mempengaruhi orang lain agar mampu berkontribusi untuk menjaga lingkungan dan mengatasi permasalahan lingkungan. Kegiatan aksi tidak langsung ini dapat berupa pembelajaran atau kampanye mengenai isu lingkungan.

Pendidikan lingkungan melalui aksi langsung dilakukan OPL di Yogyakarta melalui berbagai kegiatan, seperti aksi penanaman mangrove di pesisir selatan, pungut sampah di kawasan ruang publik, berkebun di lahan kosong perkotaan, sampai pada bersih-bersih sungai yang melintasi wilayah perkotaan. Aksi-aksi ini dilakukan baik oleh OPL bersangkutan bersama dengan masyarakat sekitar. Tujuannya adalah untuk memberikan dampak langsung bagi upaya pelestarian lingkungan sekaligus memberikan contoh kepada masyarakat akan upaya-upaya yang bisa dilakukan untuk turut serta menjaga lingkungan. Salah satunya Kemangteer melakukan pendidikan lingkungan dengan acara bertajuk Penanaman 1000 Mangrove di kawasan pantai selatan. Dalam acara ini mereka mengajak peran serta kaum muda serta masyarakat sekitar pantai untuk menanam mangrove. Dengan acara ini Kemangteer berupaya untuk memberikan dampak langsung akan upaya pelestarian lingkungan serta memberikan pelatihan kepada warga sekitar akan upaya-upaya yang bisa dilakukan untuk menjaga kelestarian daerah pesisir pantai.

Aksi tidak langsung yang berkaitan dengan pendidikan lingkungan juga turut dilakukan OPL di Yogyakarta dalam usaha untuk turut berperan mempengaruhi serta membentuk agen-agen yang bisa turut serta melakukan aksi peduli lingkungan. OPL di Yogyakarta melakukannya dalam berbagai aksi seperti melakukan pendidikan lingkungan di sekolah-sekolah muali dari tingkat SD hingga SMA, diskusi terbuka terkait lingkungan hidup, serta kampanye lewat media online. Diharapkan dengan adanya agen-agen yang memiliki pengetahuan tentang pentingnya menjaga lingkungan ini dapat ditularkan pada orang lain. Pendidikan lingkungan di sekolah dilakukan oleh beberapa OPL, diantaranya Earth Hour (EH) dengan acara bertajuk EH Sesami, Together We Save Energy (TWSE) 
dengan acara TWSE Class, Sahabat Lingkungan (Shalink) Walhi Yogyakarta dengan acara Shalink Goes To School, Hilo Green Community Jogja dengan acara School Greeneration, Sobat Bumi Jogja dengan acara Sobat Bumi Goes To School, serta Green Peace Youth Jogja dengan acara Visit School. Diskusi terbuka terkait pendidikan lingkungan juga diiniasi oleh Komunitas Mahasiswa Sentra Energi (KAMASE) membuat acara Energy Talk dan Waterplant Community dengan acara Diskusi Pengelolaan Air Bersih.

Selain itu ada pula beberapa OPL yang melakukan aksi pendidikan lingkungan dengan mencampur konsep aksi langsung dan tidak langsung. Kegiatan ini biasanya akan dimulai dengan sesi pendidikan lingkungan tidak langsung melalui diskusi dan pemberian materi. Dilanjutkan dengan sesi pendidikan lingkungan langsung berupa aksi lapangan. Seperti aksi pendidikan lingkungan yang pernah diinisiasi oleh Hilo Green Community.

Target grup merupakan kelompok tujuan dari aksi-aksi pendidikan lingkungan. Suatu pendidikan lingkungan membutuhkan target grup agar tahu kelompok sasaran mana yang akan dituju. Tentunya perbedaan target grup akan mempengaruhi isi materi serta pola penyampaian materi. Berbagai macam pendidikan lingkungan hidup telah banyak dilakukan OPL di Yogyakarta, beberapa diantaranya dilakukan dengan target grup siswa sekolah, kaum muda, dan publik secara luas.

Pertama, pendidikan lingkungan hidup yang dilakukan dengan target grup siswa sekolah dilakukan oleh berbagai OPL di Yogyakarta. Beberapa diantaranya dilakukan oleh Earth Hour (EH) Jogja, Together We Save Energy (TWSE) Community, Shalink WALHI Yogyakarta, Hilo Green Community Jogja, Sobat Bumi Jogja, dan Green Peace Youth Jogja. Masing-masing OPL dalam aksi pendidikan lingkungan bekerja sama dengan sekolah-sekolah baik dari level SD, SMP, hingga SMA untuk memberikan pengetahuan akan pentingnya menjaga lingkungan hidup. Menarik ketika sebenarnya sekolah merupakan institusi pendidikan namun materi bidang lingkungan masih dianak tirikan. Institusi pendidikan formal masih terfokus pada mata pelajaran pokok seperti Matematika, Bahasa Indonesia, Bahasa Inggris, dan sejenisnya. Pendidikan lingkungan hanya diajarkan dengan konsep pengintegrasian, yaitu sekedar disisipkan oleh para guru dalam pengajaran mata pelajaran pokok. Proses pendidikan lingkungan pada tingkat siswa sekolah ini dilakukan dengan konsep pendidikan yang menyenangkan dan tidak membebani para siswa. Adapun beberapa OPL memberikan materi penyampaian yang berbeda di tiap jenjang sekolah sesuai umur siswa yang bersangkutan.

Kedua, pendidikan lingkungan dengan target grup anak muda di Yogyakarta. Tujuan dari kegiatan ini adalah untuk memberikan kesadaran kepada generasi muda akan pentingnya pelestarian lingkungan hidup. Konsep aksi bisa berupa pemberian materi tentang lingkungan hidup, aksi di lapangan, ataupun gabungan dari keduanya, dalam upaya untuk melestarikan dan menjaga lingkungan hidup. Aksi-aksi ini pernah dilakukan oleh IAAS LC UGM, Water Forum Kalijogo, Gama Earth UGM, Forum Pelajar Peduli Lingkungan (FPPL) Jogja, Green Tech UPN, dan Koalisi Pemuda Hijau (Kophi) Jogja. Kegiatan yang ditujukan kepada kaum muda sering dilakukan karena target grup memiliki latar yang sama dengan OPL penginisiasi. Kesamaan latar belakang ini memudahkan OPL untuk menemukan celah yang bisa dimanfaatkan untuk aksi-aksi pendidikan lingkungan. Beberapa aksi dipusatkan di kampuskampus yang merupakan kantong keberadaan kaum muda Yogyakarta. Seperti yang dilakukan oleh Gama Earth UGM yang melakukan kampanye terkait penggunaan energi dan air di kampus. Tak jarang pula aksi pendidikan lingkungan untuk 
kaum muda ini dilakukan di alam terbuka, seperti yang pernah diinisiasi oleh Koalisi Pemuda Hijau (Kophi) Jogja.

Kaum muda merupakan generasi yang potensial untuk diajak melakukan perubahan, dari merekalah suatu aksi-aksi bisa dilakukan. Pada kasus di Yogyakarta kaum muda menjadi target grup yang potensial karena keberadaannya yang cukup banyak. Serta kaum muda sendiri adalah personal yang cenderung memiliki waktu luang lebih banyak yang bisa digunakan untuk berbagai kegiatan positif.

Ketiga, pendidikan lingkungan yang menyasar publik secara lebih luas. Aksi pendidikan lingkungan semacam ini pernah diinisiasi oleh Trashbag Community Yogyakarta, Waterplant Community, Pemuda Tata Ruang (Petarung), Jogja Berkebun, Komunitas Mahasiswa Sentra Energi (KAMASE), Taman Kota Jogja, Kemangteer Jogja, Sedekah Hijau, dan Youth For Climate Change DIY. Berbagai macam aksi pendidikan bisa dilakukan untuk menyasar target grup masyarakat luas. Bisa dengan kampanye tentang kepedulian lingkungan, diskusi terbuka mengenai pentingnya menjaga lingkungan, ataupun gerakan yang langsung memberi kontribusi pada lingkungan hidup. Seperti yang diinisiasi Jogja Berkebun dengan mencoba untuk memberikan pengetahuan dan pelatihan tentang berkebun di area perkotaan. Menariknya upaya untuk menarik simpati publik akan kepedulian lingkungan juga merambah ke media online. Dalam beberapa kesempatan mereka melakukan pendidikan lingkungan via akun media sosial. Akun media sosial Pemuda Tata Ruang (Petarung) dan Taman Kota Jogja senantiasa berkicau untuk menyuarakan kepedulian terhadap lingkungan. Pemuda Tata Ruang (Petarung) lebih menitik beratkan pada persoalan tata ruang di Yogyakarta, sedangkan Taman Kota Jogja menyuarakan aspirasinya akan kebutuhan ruang publik di Yogyakarta. Walaupun dengan cara yang berbeda namun cara-cara aksi pendidikan lingkungan di atas patut diapresiasi sebagai kontribusi nyata dari OPL untuk melestarikan lingkungan hidup.

\section{MEDIA ONLINE PENUNJANG AKSI PENDIDIKAN LINGKUNGAN}

OPL sesuai dengan namanya beranggotakan kaum muda di rentang usia 16-30 tahun. Salah satu ciri dari rentang usia ini adalah kedekatan mereka dengan dunia maya atau internet. Boleh jadi kebutuhan akan internet sudah menjadi kebutuhan primer bagi kaum muda. Dengan kecanggihan teknologi yang ada membuat internet bisa diakses dengan sangat mudahnya. Kini hanya dengan gawai maka semua informasi sudah bisa diakses.

Grafik 5. Kepemilikan Media Online OPL di Yogyakarta $(n=21)$.

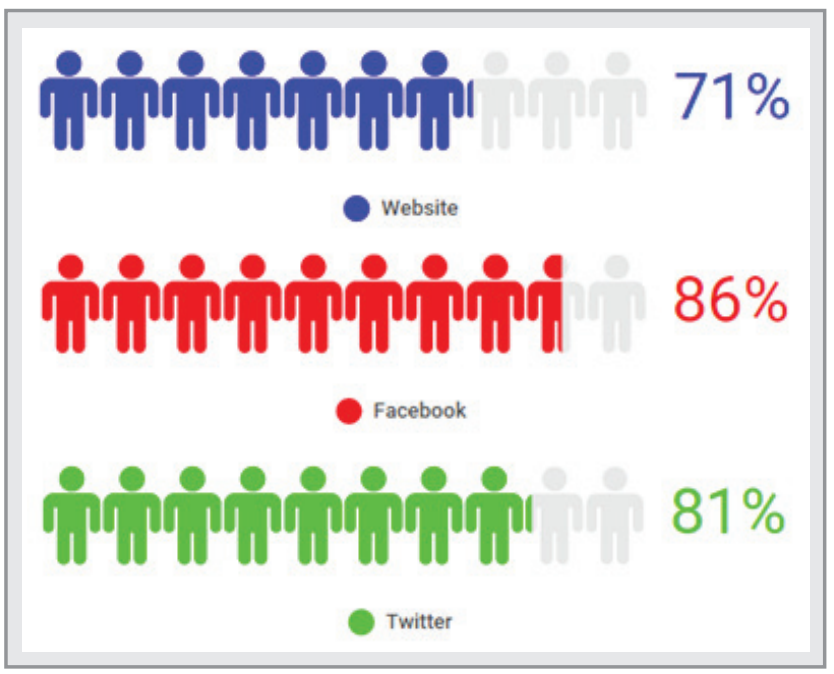

Sumber: Pengolahan Data Lapangan.

Grafik di atas memperlihatkan kepemilikan tiga media online yang populer di kalangan kaum muda, yaitu website, Facebook, dan Twitter. Kepemilikan media online menjadi hal wajib yang harus dimiliki OPL di Yogyakarta. Kepemilikan media online website, Facebook, dan Twitter berada pada kisaran $70 \%$ ke atas. Hanya Trashbag Community Yogyakarta 
dan Green Peace Youth Jogja yang tidak memiliki media online pribadi, keduanya masih memiliki media online tapi terpusat karena merupakan tipe OPL jaringan. Selebihnya bahwa dari ketiga tipe media online di atas OPL-OPL di Yogyakarta memiliki 50 media online dari 63 kemungkinan kepemilikan yang ada, atau 79\%. Atau jika dihitung berdasarkan dua media online terpopuler (Facebook dan Twitter) maka akan ditemukan hasil $83 \%$ kepemilikan. Dari sini bisa terlihat bagaimana media online telah menjadi hal yang tidak terpisahkan dari OPL di Yogyakarta. Terlebih lagi anggota dari OPL adalah kaum muda yang cenderung lebih dekat dengan dunia maya.

Perkembangan teknologi dan komunikasi mempermudah suatu organisasi maupun komunitas untuk saling bertukar informasi dan berkomunikasi. Seperti yang diungkap oleh Suharko dkk (2014) bahwa ada berbagai macam fungsi dan manfaat penggunaan media online bagi OPL. Pertama, perangkat media sosial memudahkan proses interaksi diantara para anggota dan pengurus dalam suatu organisasi atau komunitas lingkungan, dan juga diantara para anggota dan partisipan gerakan lingkungan dari berbagai organisasi atau komunitas lingkungan. Kedua, perkembangan teknologi berbasis online memudahkan aksi-aksi lingkungan yang akan dan telah dilakukan dilaporkan dan diunggah ke media online seperti laman, Facebook, Twitter dan media sosial lainnya. Ketiga, media online telah tumbuh menjadi media yang efektif untuk aksi kampanye lingkungan dan isu publik lain. Dengan makin meluasnya jangkauan pengguna media online, terlebih di kalangan muda, aksi kampanye lingkungan melalui media online bisa berlangsung secara murah, cepat dan masif. Kreatifitas dan inovasi dalam mengemas pesanpesan lingkungan akan sangat menentukan efektivitas aksi kampanye ini.

Ada banyak hal yang bisa dimanfaatkan OPL dalam hubungannya dengan media online.
Berbagai macam kelebihan media online bisa mendukung jalannya pengelolaan OPL. Pengelolaan media online yang bagus bisa dimanfaatkan dalam pengelolaan intern organisasi, ekstern organisasi, dan publikasi aksi-aksi lingkungan.

Penerapan media online dalam intern organisasi salah satunya sebagai alat komunikasi antar anggota. Banyaknya anggota yang tergabung di dalam OPL membuat mereka butuh ruang bersama yang bisa digunakan untuk berkomunikasi antar anggota. Kecanggihan teknologi mampu memenuhi kebutuhan itu dengan hadirnya berbagai macam aplikasi smartphone yang berbasis online. Aplikasi-aplikasi ini menyediakan ruang bersama yang bisa diisi oleh lebih dari dua orang untuk bisa saling berkomunikasi. Nantinya dengan aplikasi online ini anggota OPL saling berkoordinasi baik mengenai keorganisasian ataupun aksi-aksi lingkungan yang akan dilakukan. Dengan adanya aplikasi online ini akan mempermudah konsolidasi anggota OPL tanpa harus bertatap muka.

Peran media online berikutnya dalam kaitannya dengan ekstern organisasi. Tiap OPL memiliki akun media online yang beragam, mulai dari sekedar website, Facebook, Twitter, dan lainnya. Dalam penerapannya tiap akun tersebut digunakan untuk berbagai keperluan OPL. Perekrutan anggota baru OPL salah satunya dimulai dengan pembuatan poster yang nantinya diupload ke media online. Cara kovensional mungkin dilakukan dengan membuat poster yang kemudian dicetak dan ditempelkan ke beberapa spot tertentu. Namun di tengah berkembangnya media online membuat cara-cara konvensional tersebut tak lagi digunakan. OPL cukup membuat poster dalam bentuk softfile dan diedarkan lewat media online. Cara ini terbukti lebih efektif baik dari segi waktu dan pendanaan. Apalagi target grup dalam upaya untuk mengajak bergabung ke dalam OPL ini tentunya kaum muda yang dekat dengan dunia online.

Menariknya aksi-aksi pendidikan lingkungan 
yang dilakukan OPL sebisa mungkin dipublikasikan ke masyarakat, salah satunya dengan media online. Bukan hanya sebagai ajang pamer aksi dari masingmasing OPL, tapi di era sekarang media online menjadi senjata paling ampuh untuk mempublikasikan acara. Suatu aksi lingkungan biasanya membutuhkan publikasi dalam tiga fase yang berbeda, yaitu pra acara, pada saat acara berlangsung, dan pasca acara. Dalam ketiga fase inilah peran media online sangat penting.

Pra aksi biasanya media online digunakan untuk menyebar pemberitahuan akan aksi yang akan dilakukan. Baik itu sekedar pemberitahuan biasa ataupun ajakan untuk mengikuti aksi lingkungan yang diinisiasi OPL yang bersangkutan. Tujuan dari pembuatan pengumuman atau poster ini utamanya untuk mengajak keikutsertaan masyarakat ataupun kaum muda lain untuk turut berpartisipasi. Di sisi lain kegunaannya adalah sebagai ajang publikasi bahwa OPL yang bersangkutan akan melakukan suatu aksi lingkungan.

Media online juga dimanfaatkan OPL ketika aksi pendidikan lingkungan berlangsung, biasanya dilakukan dengan metode livetweet baik berupa gambar, video, ataupun keterangan atas aksi yang baru dilakukan. Dengan konsep livetweet maka OPL dapat menyampaikan kegiatan apa yang sedang mereka lakukan kepada masyarakat. Cara ini mirip dengan sistematika jurnalisme online, di mana akun media online dari OPL tersebut mencoba untuk secepat mungkin mengabarkan kejadiankejadian dalam aksi lingkungan mereka.

Terakhir media online dimanfaatkan sebagai ajang berbagi informasi atas aksi lingkungan yang berhasil dilaksanakan atau pasca aksi lingkungan dilakukan. OPL memiliki kebutuhan untuk mengaktualisasikan diri melalui 'laporan' aksiaksi lingkungan yang berhasil mereka lakukan, dan sarana yang paling efektif lewat media online. Nantinya dengan mengunggah beberapa hal terkait aksi lingkungan yang telah terjadi akan menjadi bukti bahwa OPL tersebut telah eksis dan mampu berkontribusi dalam upaya gerakan lingkungan. Selain itu OPL juga membutuhkan sarana untuk mengabadikan setiap aksi lingkungan yang mereka inisiasi. Pengunggahan aksi lewat media online ini juga berfungsi sebagai dokumentasi aksi-aksi yang pernah mereka lakukan.

Media online juga bisa menjadi media aksi lingkungan seperti yang dilakukan beberapa OPL di Yogyakarta. Dengan akun media online yang dimiliki, OPL tersebut melakukan kampanye lingkungan dengan berbagai unggahan tulisan dan gambar. Cara ini tergolong unik karena dilakukan di dunia maya, proses penyampaiannya pun otomatis menyasar para pemakai media online. Cara seperti ini lazim dilakukan oleh Pemuda Tata Ruang (Petarung) dan Taman Kota Jogja, keduanya sering melakukan aksi-aksi pendidikan lingkungan melalui akun media online yang mereka miliki. Sistematikanya dengan melakukan kultweet yang berisi informasi atau pesan-pesan terkait lingkungan hidup.

Tak bisa dipungkiri media online sudah menjadi kebutuhan bagi sebagian besar kaum muda di Yogyakarta. Begitu pula ketika mereka berkumpul dalam OPL media online tak bisa lepas untuk menjadi kebutuhan. Hasilnya memang media online bisa dimanfaatkan sebaik mungkin untuk ikut menunjang pengelolaan organisasi. OPL di Yogyakarta yang masih bertahan dan eksis hampir semuanya menggunakan media online sebagai salah satu bagian yang tak terpisahkan dalam menunjang aksi-aksi pendidikan lingkungan.

\section{KESIMPULAN}

Yogyakarta terkenal sebagai salah satu kota besar di Indonesia dengan predikat kota pendidikan. Seiring banyaknya kaum muda maka tumbuh juga berbagai komunitas maupun organisasi yang didirikan dan berisi mayoritas kaum muda. Salah satu yang 
menarik adalah kehadiran Organisasi Pemuda Lingkungan (OPL) di Yogyakarta, OPL ini didirikan sebagai bagian dari kegelisahan kaum muda akan berbagai permasalahan lingkungan yang diiringi dengan rendahnya kesadaran akan lingkungan.

Salah satu kegiatan yang paling sering diinisiasi oleh OPL adalah aksi pendidikan lingkungan. Aksi-aksi pendidikan lingkungan yang dilakukan OPL di Yogyakarta adalah salah satu bagian dari gerakan lingkungan di Indonesia. Gerakan lingkungan ini termasuk dalam komponen organized/ voluntary environmentalist, yaitu gerakan lingkungan diinisiasi oleh organisasi-organisasi yang memang didirikan untuk memperbaiki lingkungan hidup. Pendidikan lingkungan para OPL ini juga termasuk dalam tipe non-formal karena diinisiasi bukan oleh sekolah atau institusi formal. Para OPL ini telah mengambil peran untuk turut serta dalam proses pendidikan lingkungan hidup. Berbagai peran dalam pendidikan lingkungan mereka lakukan baik sebagai kreator ataupun pelaksana pendidikan lingkungan itu sendiri. Pendidikan lingkungan yang diinisiasi oleh OPL dilakukan dalam aksi langsung maupun tidak langsung. Target grupnya pun menyeluruh mulai dari level sekolah sampai pada publik secara lebih luas.

Salah satu faktor yang turut mendukung upaya pendidikan lingkungan di Yogyakarta adalah media online. Sejatinya keberadaan media online sangat erat dengan kaum muda yang merupakan anggota dari OPL sebagai aktor utama jejaring pendidikan lingkungan di Yogyakarta. Media online berperan sebagai salah satu media yang digunakan OPL untuk melakukan konsolidasi internal. Keterbatasan ruang dan jarak dimanfaatkan pengurus OPL untuk menggunakan media online sebagai sarana berkomunikasi antar anggota. Selain itu media online turut berperan serta dalam pelaksanaan aksi pendidikan lingkungan baik sebelum aksi, ketika aksi dilakukan, dan setelah aksi. Dalam hal ini peran media online sebagai sarana publikasi eksternal.

\section{DAFTAR PUSTAKA}

Abercrombie, Nicholas, et. al.. 2010. Kamus Sosiologi. Yogyakarta: Pustaka Pelajar.

Aditjondro, George Junus. 2003. Pola-pola Gerakan Lingkungan, Refleksi untuk Menyelamatkan Lingkungan dari Ekspansi Modal. Yogyakarta: Pustaka Pelajar.

Azca, M. Najib., et. al., (ed). 2011. Pemuda Pasca-Orde Baru, Potret Kontemporer Pemuda Indonesia. Yogyakarta: YouSure.

Azca, M. Najib., et. al.. 2014. Karakteristik Pemuda dan Kecenderungan Perilaku Kekerasan di Kota Yogyakarta dan Surakarta. Yogyakarta: YouSure.

Holmes, David. 2005. Communication Theory: Media, Technology, and Society. London: Sage Publications.

Jensen, Bjarne Bruun \& Schnack, Karsten. The Action Competence Approach in Environmental Education. Environmental Education Research Volume 3, Nomor 2, 1997. Joga, Nirwono. 2013. Gerakan Kota Hijau. Jakarta: PT Gramedia Pustaka Utama.

Keraf, A. Sonny. 2010. Krisis dan Bencana Lingkungan Hidup Global. Yogyakarta: Kanisius.

Nomura, Ko. 2000. Present State of the Environmental Education Network in Indonesia. Japan: Institute for Global Environmental Strategies (IGES).

Nomura, Ko, and Hendarti, Latipah (ed). 2005. Environmental Education and NGOs in Indonesia. Jakarta: Yayasan Obor Indonesia. Suharko, (ed). 2006. Gerakan Sosial: Konsep, Strategi, Aktor, Hambatan, dan tantangan Gerakan Sosial di Indonesia. Malang: Averroes Press.

Suharko. 2005. Merajut Demokrasi, Hubungan NGO, Pemerintah, dan Pengembangan Tata Pemerintahan Demokratis (1966-2001). Yogyakarta: Tiara Wacana.

Suharko. 2006. "Gerakan Sosial Baru di Indonesia: Repertoar Gerakan Petani”, dalam Jurnal Ilmu Sosial dan Ilmu Politik vol. 10 no 1, 1-34.

Suharko, et. al.. 2014. Organisasi Pemuda Lingkungan di Indonesia Pasca-Orde Baru. Yogyakarta: Gadjah Mada University Press. 